\title{
CHANGES IN THE ELECTROPHORETIC PATTERN IN LYMPH AND SERUM IN EXPERIMENTAL BURNS
}

\author{
By G. E. PERLMANN, W. W. L. GLENN,1 and D. KAUFMAN \\ (From the Departments of Medicine of the Massachusetts General Hospital and \\ Harvard Medical School,2 and from the Department of Physiology of \\ the Harvard School of Public Health, Boston)
}

(Received for publication May 11, 1943)

In a previous paper, changes in the content of nitrogenous compounds in blood and lymph of calves in response to burns were described (1). At the same time, opportunity was provided for the study of the proteins of lymph and serum. In recent years, physico-chemical methods have been devised to identify many different types of proteins in the mixture existing in plasma. Among these is the technique of electrophoretic analysis perfected by Tiselius. By the application of this method, certain detailed changes in the protein picture may be discerned with precision and the method has received widespread application. There have been, however, no reports in the literature of analyses of lymph by the Tiselius technique and it has been assumed that lymph proteins are identical with those found in plasma. The present experiments tend to confirm this identity, and at the same time, it became possible to study the variations in the electrophoretic patterns of normal lymph, of lymph from severely burned tissues, and of serum collected before and after burning.

\section{EXPERIMENTAL}

Material. Calves 2 to 4 months old and weighing from 125 to 200 pounds were chosen for the experiments. The detailed description of the technique of burning has been published previously (1). Lymph was collected by cannulating both foreleg lymphatics. By burning only one foreleg, for $1 \frac{1}{2}$ to 4 minutes with boiling water, lymph from a burned and an unburned leg could be obtained simultaneously. Blood samples were withdrawn from the jugular vein before the burn and at varying intervals during the experiment. The so-called "tissue fluid" was obtained by inserting a blunt needle into the edematous

1 First Lieutenant, M. C., A. U. S.

2 This is publication No. 70 of the Robert W. Lovett Memorial for the study of crippling disease, Harvard Medical School. The expenses of this investigation were defrayed in large part by a grant from the Commonwealth Fund. subcutaneous tissue of the burned leg. After clotting, the different specimens were centrifuged and the supernatant fluids frozen and stored at $-12^{\circ} \mathrm{C}$. until the electrophoretic measurements were made.

Electrophoretic technique. The electrophoretic experiments were performed at $1.5^{\circ} \mathrm{C}$. in the apparatus described by Tiselius (2). The Toepler Schlieren method with the modification of Longsworth (3) was used for obtaining a photographic record of the protein migration. All protein samples were diluted to a final concentration of 1.3 or 2.0 per cent with the buffer to be used in the electrophoretic study, and were then dialyzed against $\mathbf{5 0 0}$ cc. of this buffer for 24 hours and finally, against 2000 cc. for 24 hours or longer. In the electrophoretic cell of Tiselius, "double section cell," a 1.3 per cent solution was used; in the "single section cell," as first described by Longsworth (4), the protein concentration was 2.0 per cent.

Most of the experiments were done in potassium phosphate buffer at a $\mathrm{pH}$ of 7.7 and an ionic strength of 0.2. Sodium diethylbarbiturate buffer of $\mathrm{pH} 8.6$ and ionic strength 0.1 was used in some determinations.

\section{RESULTS}

Measurements were carried out on the serum and lymph from 5 animals. In all, 60 separate electrophoretic experiments were made. Only representative data for each animal are given; all results, however, are consistent with the ones represented. In Figures $1 \mathrm{~A}, 1 \mathrm{~B}$, and 2, typical patterns are shown. The relative concentrations have been estimated by the procedure of Tiselius and Kabat (5), and are listed in Tables I and II. Only the values from the descending migration patterns are recorded. In all experiments, however, the corresponding values calculated from the ascending patterns check within 1 per cent.

The electrophoretic method does not separate the serum proteins into components which are homogeneous in respect to size, shape, isoelectric point, or distribution of charge. The relative amount of protein in a given electrophoretic component can, therefore, vary with the $\mathrm{pH}$ of the measurement. The mobility, which is used for 
A. BEFORE BURN
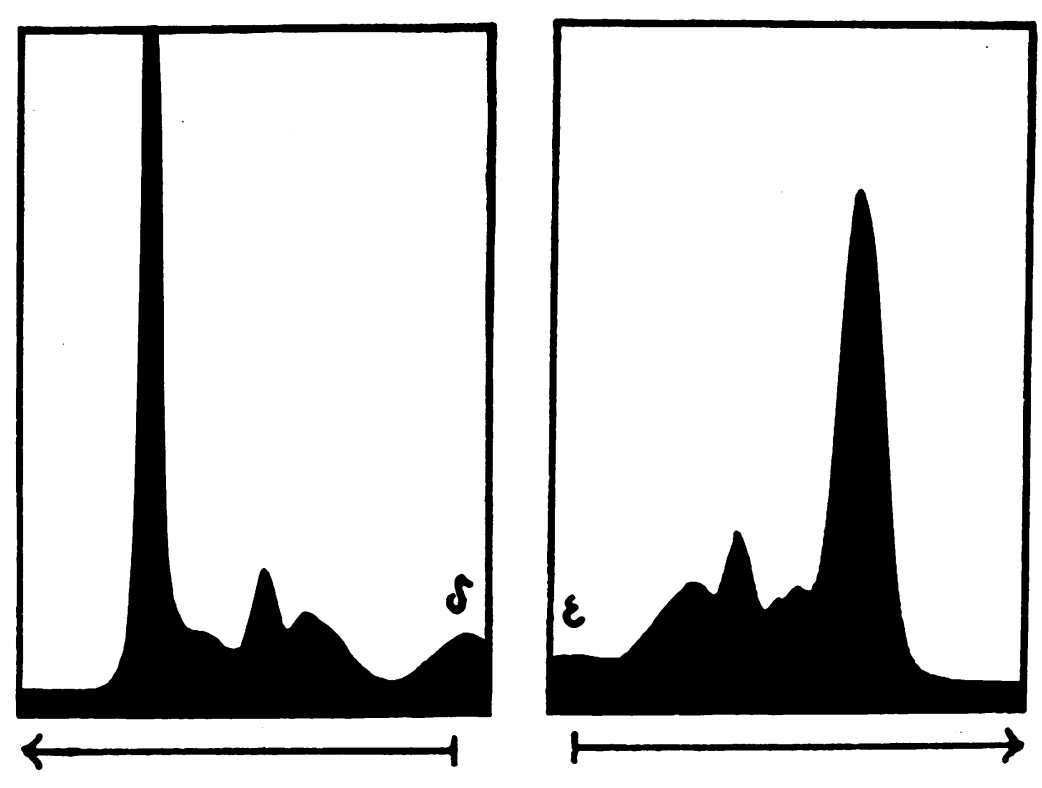

B. AFTER BURN UNBURNED LEG
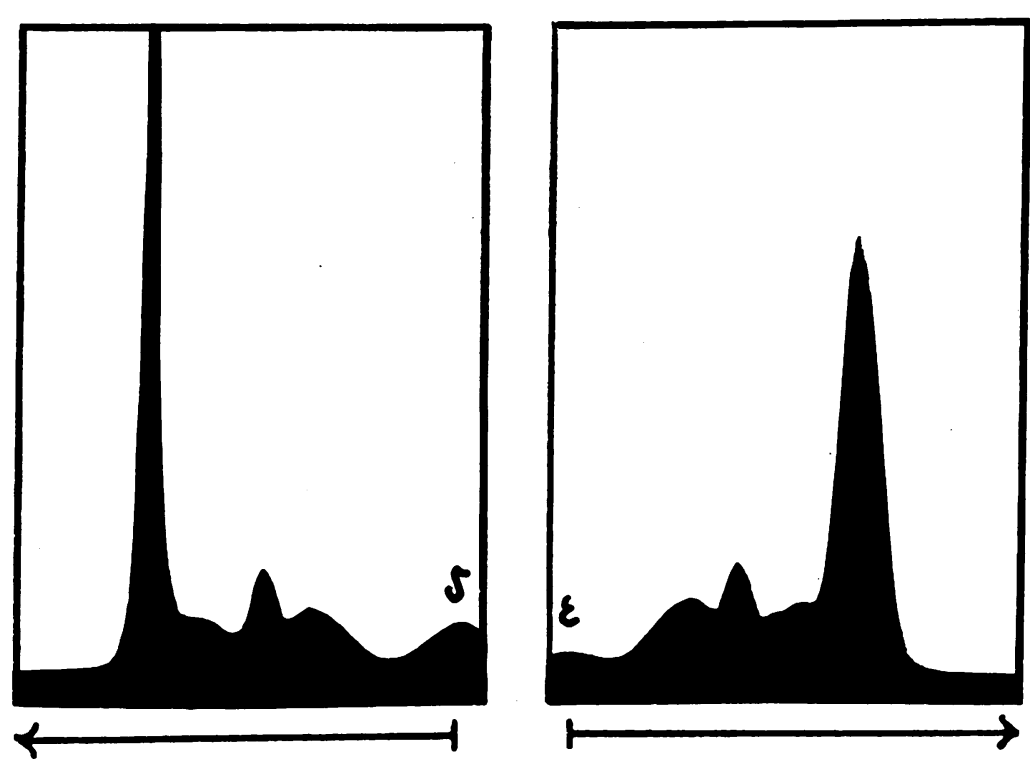

C. AFTER BURN BURNED LEG
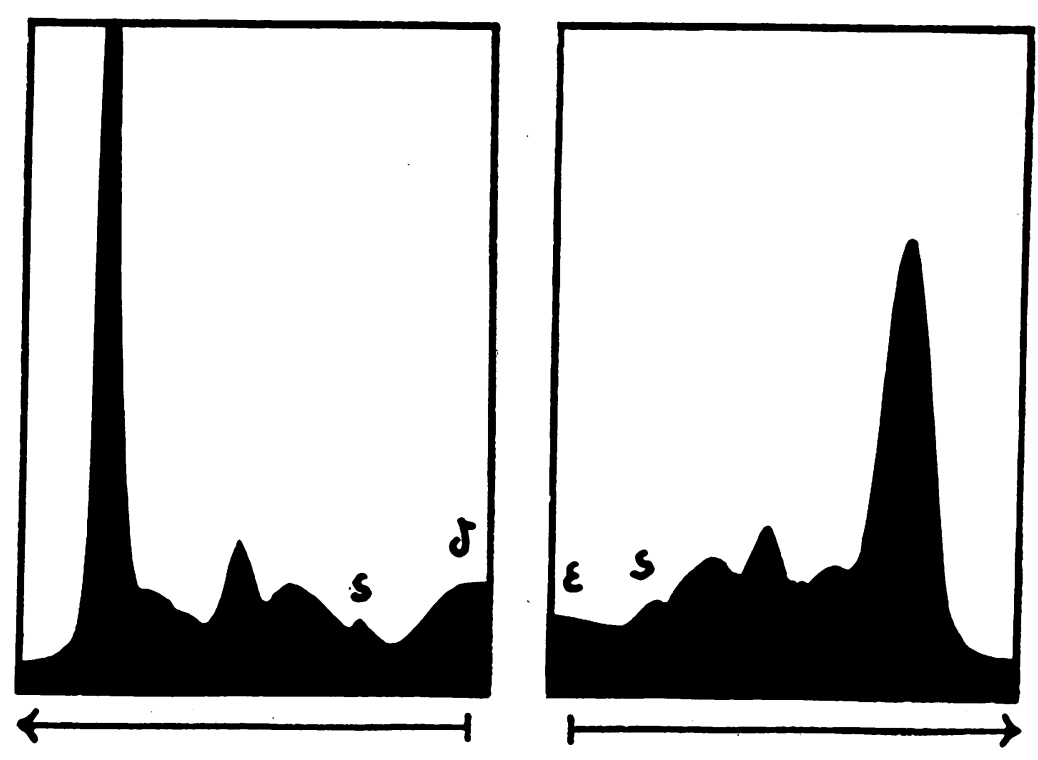
identification in the electrophoretic analysis, varies as a function of the $\mathrm{pH}$ and the ionic strength (6). Therefore, the diagrams obtained at different $\mathrm{pH}$ 's are not strictly comparable. Differences were noted with the two buffers used in the experiments described in this paper. The separation of albumin and $\alpha$-globulin was more complete in sodium diethylbarbiturate at $\mathrm{pH} 8.6$ (compare Longsworth (7)), whereas no clear separation of the $\beta$ - and $\gamma$-fractions could be obtained in this buffer.

Normal lymph and normal serum. Our measurements of the normal sera and lymph of calves reveal differences among individual animals with respect to the distribution of the protein among the various electrophoretic components. This observation of individual variation is in agreement with the data reported from other laboratories ( 8 to 10$)$. In 3 of the experiments on serum described in this paper, the peak ascribed to $\gamma$-globulin was distinctly double in both the descending and the ascending patterns. A similar observation has been made by Svensson (9). In several experiments, the $\alpha$-globulin of lymph revealed inhomogeneity $\left(\alpha_{1}\right.$ and $\left.\alpha_{2}\right)$. The separation, however, was incomplete and the results are therefore evaluated in terms of the classification first suggested by Tiselius in 1937, namely: albu$\min , \alpha-, \beta$-, and $\gamma$-globulin.

A $\beta$-boundary disturbance occurring in human serum and plasma was first described by Longsworth, Shedlovsky, and MacInnes (11). Svensson (9) noticed a similar phenomenon in bovine serum. We have observed that the split of the $\beta$ boundary into two peaks on the "descending" side of the cell occurred more readily in sodium diethylbarbiturate at $\mathrm{pH} 8.6$ than in phosphate at $\mathrm{pH}$ 7.7. In the latter case, it could only be obtained after electrophoresis for 3 to 4 hours, at a potential gradient of 4 volts per centimeter, and a protein concentration exceeding 2.2 per cent. This observation may be suggestive of a change in the interaction of the proteins present, due to

Fig. 1A. Electrophoretic Patterns of Lymph (EXPERIMENT 11)

The patterns were obtained from a 2.0 per cent protein solution in phosphate buffer at $\mathrm{pH} 7.7$ and an ionic strength of 0.2 , after electrophoresis for 12,600 seconds at 3.81 volts per centimeter.
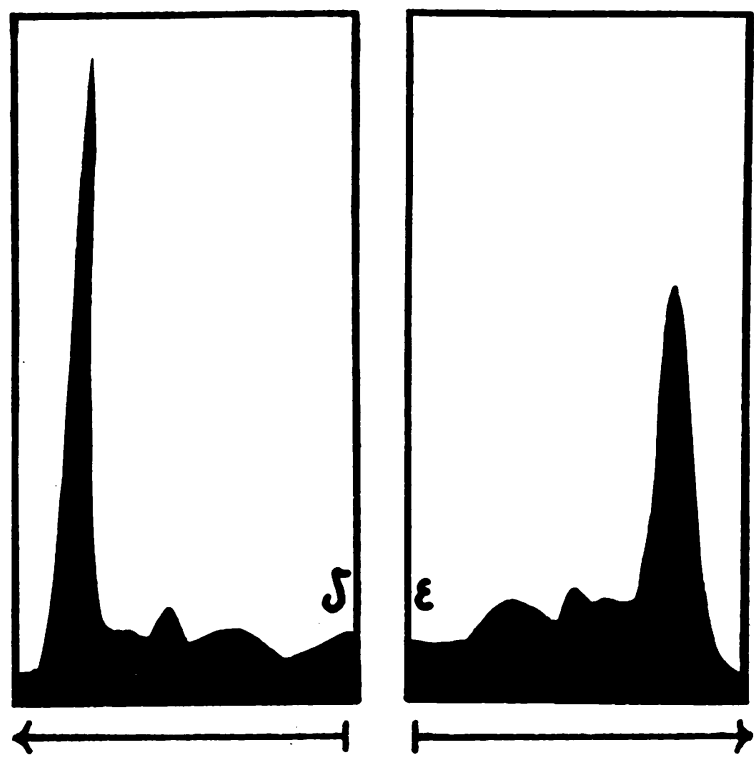

\section{A. AFTER BURN UNBURNED LEG}
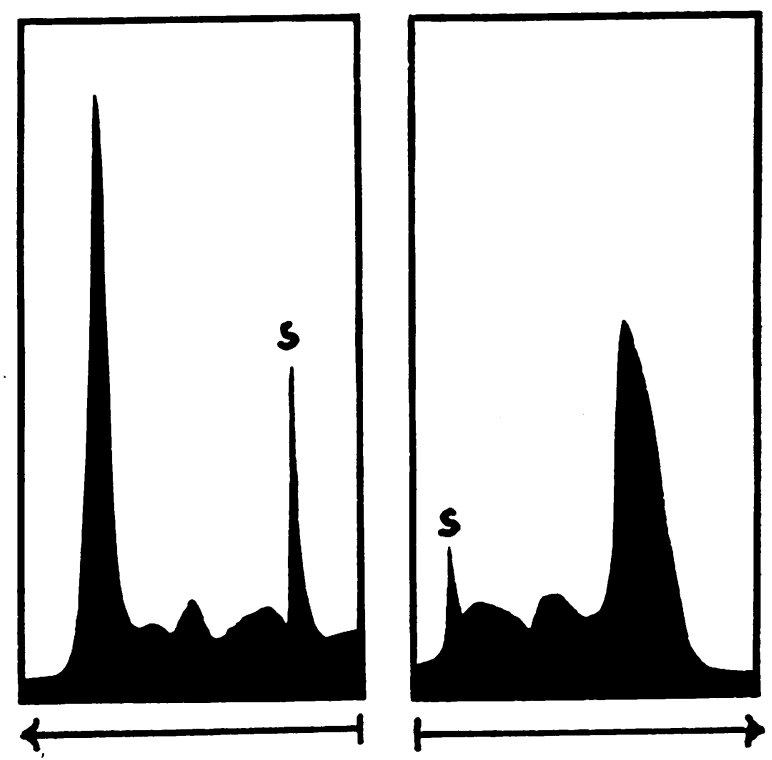

B. AFTER BURN

\section{BURNED LEG}

Fig. 1B. Electrophoretic Patterns of Lymph (EXPERIMENT 4)

The patterns were obtained from a 1.3 per cent protein solution in phosphate buffer at $\mathrm{pH} 7.7$ and an ionic strength of 0.2 , after electrophoresis for 10,800 seconds at 4.12 volts per centimeter. 

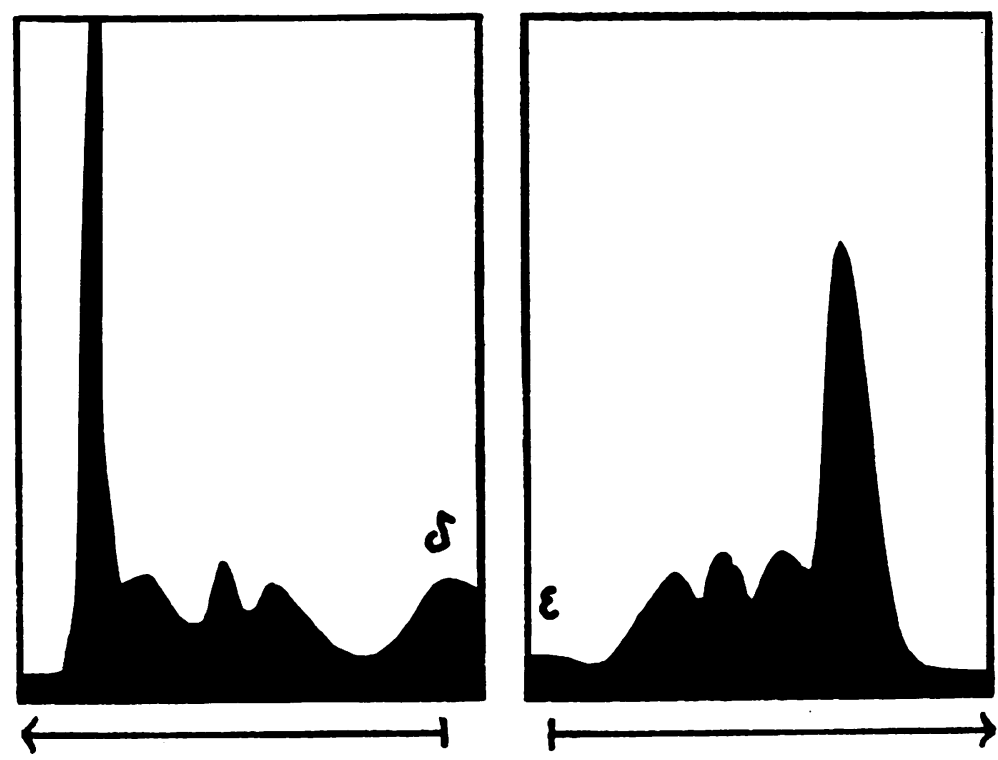

A. BEFORE BURN
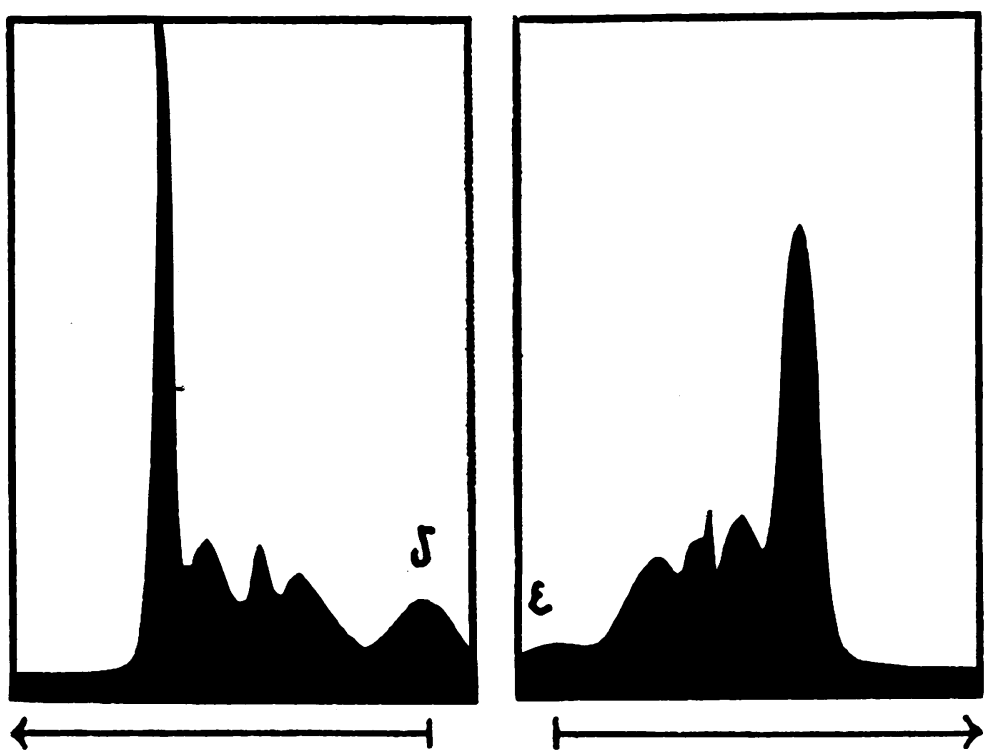

B. AFTER BURN

Fig. 2. Electrophoretic Patterns of Serum (Experiment 11)

The patterns were obtained from a 2.0 per cent protein solution in phosphate buffer at $\mathrm{pH} 7.7$ and an ionic strength of 0.2 , after electrophoresis for 14,400 seconds (A), and 12,600 seconds (B), at 3.84 volts per centimeter. The protein concentration of $\mathrm{B}$ was 1.8 per cent. 
TABLE I

Electrophoretic distribution of proteins in lymph

\begin{tabular}{|c|c|c|c|c|c|c|c|c|c|c|c|c|c|c|}
\hline \multirow{3}{*}{$\begin{array}{l}\text { Experi- } \\
\text { ment } \\
\text { number }\end{array}$} & \multirow{3}{*}{ Lymph } & \multirow{3}{*}{$\begin{array}{c}\text { Time after } \\
\text { burn }\end{array}$} & \multirow{3}{*}{$\mathrm{pH}$} & \multirow{3}{*}{$\begin{array}{l}\text { Total } \\
\text { protein }\end{array}$} & \multicolumn{5}{|c|}{ Concentrations in per cent as } & \multicolumn{5}{|c|}{$\begin{array}{c}\text { Mobilities } \\
\mathrm{cm} .^{2} \cdot \text { volt }^{-1} \cdot \text { sec. }^{-1} \cdot 10^{-5}\end{array}$} \\
\hline & & & & & \multirow{2}{*}{$\begin{array}{c}\text { Al- } \\
\text { bumin }\end{array}$} & \multicolumn{3}{|c|}{ Globulins } & \multirow{2}{*}{$\mathbf{s}$} & \multirow{2}{*}{$\begin{array}{l}\mathrm{Al}- \\
\text { bumin }\end{array}$} & \multicolumn{3}{|c|}{ Globulins } & \multirow{2}{*}{$\mathbf{s}$} \\
\hline & & & & & & $\alpha$ & $\beta$ & $\gamma$ & & & $\alpha$ & $\beta$ & $\gamma$ & \\
\hline 2 & $\begin{array}{l}\text { Before burn } \\
\text { After burn: Burned leg }\end{array}$ & $\begin{array}{c}\text { hours } \\
0 \\
14 \text { to } 16\end{array}$ & 7.7 & $\begin{array}{c}\text { grams per } \\
100 \text { cc. } \\
2.87 \\
3.90\end{array}$ & $\begin{array}{l}67.6 \\
43.1\end{array}$ & $\begin{array}{r}5.1 \\
14.6\end{array}$ & $\begin{array}{l}11.4 \\
13.1\end{array}$ & $\begin{array}{l}15.9 \\
29.2\end{array}$ & & $\begin{array}{l}6.1 \\
6.1\end{array}$ & $\begin{array}{l}4.6 \\
4.6\end{array}$ & $\begin{array}{l}3.7 \\
3.6\end{array}$ & $\begin{array}{l}1.9 \\
1.9\end{array}$ & \\
\hline 4 & $\begin{array}{l}\text { Before burn } \\
\text { After burn: Unburned leg } \\
\text { Burned leg }\end{array}$ & $\begin{array}{l}0 \\
3 \text { to } 8 \\
3 \text { to } 8\end{array}$ & 7.7 & $\begin{array}{l}3.34 \\
3.73 \\
3.91\end{array}$ & $\begin{array}{l}63.2 \\
61.2 \\
54.6\end{array}$ & $\begin{array}{l}9.2 \\
8.9 \\
6.3\end{array}$ & $\begin{array}{l}10.5 \\
10.7 \\
12.6\end{array}$ & $\begin{array}{l}17.1 \\
19.2 \\
15.0\end{array}$ & $11.5^{*}$ & $\begin{array}{l}6.0 \\
6.1 \\
6.1\end{array}$ & $\begin{array}{l}4.6 \\
4.7 \\
4.6\end{array}$ & $\begin{array}{l}3.6 \\
3.7 \\
3.7\end{array}$ & $\begin{array}{l}1.9 \\
1.9 \\
1.9\end{array}$ & 0.9 \\
\hline 11 & $\begin{array}{l}\text { Before burn } \\
\text { After burn: Unburned leg } \\
\text { Burned leg }\end{array}$ & $\begin{array}{l}0 \\
2 \text { to } 5 \\
2 \text { to } 5\end{array}$ & 7.7 & $\begin{array}{l}2.47 \\
2.74 \\
3.58\end{array}$ & $\begin{array}{l}63.1 \\
63.6 \\
59.4\end{array}$ & $\begin{array}{r}9.4 \\
9.2 \\
10.1\end{array}$ & $\begin{array}{l}12.4 \\
12.7 \\
12.0\end{array}$ & $\begin{array}{l}15.1 \\
14.5 \\
14.5\end{array}$ & 4.0 & $\begin{array}{l}6.3 \\
6.1 \\
6.1\end{array}$ & $\begin{array}{l}4.8 \\
4.5 \\
4.5\end{array}$ & $\begin{array}{l}3.7 \\
3.5 \\
3.5\end{array}$ & $\begin{array}{l}2.2 \\
2.1 \\
2.1\end{array}$ & 1.1 \\
\hline 6 & $\begin{array}{l}\text { Before burn } \\
\text { After burn: Burned leg }\end{array}$ & $\begin{array}{c}0 \\
6 \text { to } 8\end{array}$ & 8.6 & $\begin{array}{l}2.46 \\
3.56\end{array}$ & $\begin{array}{l}63.0 \\
55.4\end{array}$ & $\begin{array}{l}14.8 \\
15.1\end{array}$ & $\begin{array}{l}15.1 \\
14.4\end{array}$ & $\begin{array}{l}8.1 \\
8.1\end{array}$ & 7.0 & & & & & \\
\hline 8 & $\begin{array}{l}\text { Before burn } \\
\text { After burn: Unburned leg } \\
\text { Burned leg }\end{array}$ & $\begin{array}{l}0 \\
6 \text { to } 8 \\
6 \text { to } 8\end{array}$ & 8.6 & $\begin{array}{l}2.90 \\
2.75 \\
3.60\end{array}$ & $\begin{array}{l}58.0 \\
60.0 \\
49.7\end{array}$ & $\begin{array}{l}16.6 \\
14.6 \\
15.6\end{array}$ & $\begin{array}{l}15.4 \\
13.1 \\
19.1\end{array}$ & $\begin{array}{r}10.0 \\
12.3 \\
9.9\end{array}$ & 5.7 & $\begin{array}{l}7.5 \\
7.7 \\
7.7\end{array}$ & $\begin{array}{l}5.5 \\
5.4 \\
5.6\end{array}$ & $\begin{array}{l}3.3 \\
3.5 \\
3.4\end{array}$ & $\begin{array}{l}2.1 \\
2.2 \\
2.2\end{array}$ & 1.1 \\
\hline
\end{tabular}

* Separation incomplete.

TABLE II

Electrophoretic distribution of proteins in serum

\begin{tabular}{|c|c|c|c|c|c|c|c|c|c|c|c|c|}
\hline \multirow{3}{*}{$\begin{array}{l}\text { Experiment } \\
\text { number }\end{array}$} & \multirow{3}{*}{ Serum } & \multirow{3}{*}{$\underset{\text { burn }}{\text { Time after }}$} & \multirow{3}{*}{$\mathrm{pH}$} & \multirow{3}{*}{$\begin{array}{l}\text { Total } \\
\text { protein }\end{array}$} & \multicolumn{4}{|c|}{ Concentrations in per cent as } & \multicolumn{4}{|c|}{$\underset{\text { cm. }^{2} \cdot \text { volt }^{-1} \cdot \text { sec. }^{-1} \cdot 10^{-5}}{\text { Mobilities }}$} \\
\hline & & & & & \multirow{2}{*}{ Albumin } & \multicolumn{3}{|c|}{ Globulins } & \multirow{2}{*}{ Albumin } & \multicolumn{3}{|c|}{ Globulins } \\
\hline & & & & & & $\alpha$ & $\boldsymbol{\beta}$ & $\gamma$ & & $\alpha$ & $\boldsymbol{\beta}$ & $\gamma$ \\
\hline 2 & $\begin{array}{l}\text { Before burn } \\
\text { After burn }\end{array}$ & $\begin{array}{c}\text { hours } \\
0 \\
19\end{array}$ & 7.7 & $\begin{array}{c}\text { grams per } \\
100 \text { cc. } \\
6.04 \\
5.34\end{array}$ & $\begin{array}{l}55.8 \\
52.0\end{array}$ & $\begin{array}{l}11.4 \\
12.8\end{array}$ & $\begin{array}{l}12.7 \\
12.8\end{array}$ & $\begin{array}{l}20.1 \\
22.4\end{array}$ & $\begin{array}{l}6.1 \\
6.1\end{array}$ & $\begin{array}{l}4.6 \\
4.7\end{array}$ & $\begin{array}{l}3.6 \\
3.7\end{array}$ & $\begin{array}{l}1.9 \\
1.9\end{array}$ \\
\hline 4 & $\begin{array}{l}\text { Before burn } \\
\text { After burn }\end{array}$ & $\begin{array}{r}0 \\
5 \\
11\end{array}$ & 7.7 & $\begin{array}{l}6.75 \\
7.53 \\
6.43\end{array}$ & $\begin{array}{l}61.0 \\
40.3 \\
38.8\end{array}$ & $\begin{array}{r}9.8 \\
10.3 \\
13.1\end{array}$ & $\begin{array}{r}8.9 \\
11.2 \\
8.2\end{array}$ & $\begin{array}{l}20.3 \\
38.2 * \\
39.9 *\end{array}$ & $\begin{array}{l}6.2 \\
6.2 \\
6.1\end{array}$ & $\begin{array}{l}4.6 \\
4.9 \\
4.8\end{array}$ & $\begin{array}{l}3.6 \\
3.8 \\
3.6\end{array}$ & $\begin{array}{l}1.9 \\
1.9 \\
1.9\end{array}$ \\
\hline 11 & $\begin{array}{l}\text { Before burn } \\
\text { After burn }\end{array}$ & $\begin{array}{c}0 \\
9 \frac{1}{2} \\
19 \frac{1}{2}\end{array}$ & 7.7 & $\begin{array}{l}5.44 \\
5.14 \\
5.14\end{array}$ & $\begin{array}{l}55.8 \\
54.6 \\
51.9\end{array}$ & $\begin{array}{l}13.2 \\
13.1 \\
17.2\end{array}$ & $\begin{array}{l}14.8 \\
16.4 \\
12.9\end{array}$ & $\begin{array}{l}16.2 \\
15.9 \\
18.0\end{array}$ & $\begin{array}{l}6.0 \\
6.0 \\
5.9\end{array}$ & $\begin{array}{l}4.6 \\
4.6 \\
4.5\end{array}$ & $\begin{array}{l}3.5 \\
3.6 \\
3.6\end{array}$ & $\begin{array}{l}2.0 \\
2.1 \\
2.1\end{array}$ \\
\hline 6 & $\begin{array}{l}\text { Before burn } \\
\text { After burn }\end{array}$ & $\begin{array}{r}0 \\
12 \\
18\end{array}$ & 8.6 & $\begin{array}{l}6.30 \\
5.32 \\
4.76\end{array}$ & $\begin{array}{l}53.7 \\
49.3 \\
52.1\end{array}$ & $\begin{array}{l}19.4 \\
23.7 \\
21.6\end{array}$ & $\begin{array}{l}17.5 \\
17.8 \\
17.7\end{array}$ & $\begin{array}{l}9.4 \\
9.2 \\
8.6\end{array}$ & & & & \\
\hline 8 & $\begin{array}{l}\text { Before burn } \\
\text { After burn }\end{array}$ & $\begin{array}{r}0 \\
6 \\
18\end{array}$ & 8.6 & $\begin{array}{l}6.19 \\
5.55 \\
5.00\end{array}$ & $\begin{array}{l}55.1 \\
53.1 \\
49.5\end{array}$ & $\begin{array}{l}16.0 \\
15.8 \\
20.1\end{array}$ & $\begin{array}{l}16.5 \\
16.6 \\
16.1\end{array}$ & $\begin{array}{l}12.4 \\
14.5 \\
14.3\end{array}$ & $\begin{array}{l}7.1 \\
7.3 \\
7.1\end{array}$ & $\begin{array}{l}5.0 \\
5.1 \\
5.0\end{array}$ & $\begin{array}{l}3.0 \\
3.1 \\
3.0\end{array}$ & $\begin{array}{l}1.9 \\
2.0 \\
1.9\end{array}$ \\
\hline
\end{tabular}

* Samples hemolysed, compare text. 
small changes in the salt concentration. Incidentally, the $\beta$ disturbance could not be observed in the electrophoresis of lymph proteins.

The electrophoretic migration pattern of normal lymph revealed the same 4 components as are present in serum. As can be seen by comparison of the concentration of the protein components of lymph recorded in Table I with the corresponding values of serum listed in Table II, the relative amount of albumin is invariably higher in lymph than in serum.

The patterns obtained from lymph and serum after the animals were subjected to burns are in marked contrast to the normal.

Lymph and serum after burn. All samples of lymph collected from burned legs show a decrease of the albumin: globulin ratio and a disturbance in the slow globulin fraction. The patterns in 4 of the 5 experiments performed indicate the occurrence of a new boundary migrating more slowly than the $\gamma$-globulin, which we shall call the "s" fraction. In the fifth case (Experiment 2), while no " $\mathrm{s}$ " component separated, a marked increase of the $\gamma$-globulin was observed. This experiment was the first performed, and the absence of this new component may well have been due to the low protein concentration used in the electrophoretic analysis, too low to permit resolution. We have found the new component in all samples of lymph collected from the burned legs, both when the electrophoresis was carried out in sodium diethylbarbiturate buffer at $\mathrm{pH} 8.6$ and, when in phosphate buffer, the protein concentration exceeded 1.8 per cent; however, 3 to 4 hours were required for the separation of this component from the $\gamma$-globulin and the $\delta$ and $\epsilon$ enomalies (12) in the latter buffer. The " $s$ " fraction migrates with half the speed of the $\gamma$-globulin and was found in concentrations varying from 5 to 15 per cent of the total protein. It was maintained in constant concentration in lymph throughout the experimental period of 10 to 16 hours. This component was never found in lymph collected simultaneously from the unburned leg.

This striking difference in the composition of lymph derived from the burned and unburned areas made it advisable to test "tissue fluid" collected from the burned tissue directly. Samples of fluids were obtained in two experiments (Experiments 8 and 11), and both showed disturbances of the slow component similar to those found in the lymph from the burned legs, collected during the same period. In Experiment 8, using sodium diethylbarbiturate buffer, the slow moving "s" component separated out. In Experiment 11, phosphate buffer was used, and the pattern revealed an increase in the $\gamma$-fraction. The data are listed in Table III.

The changes found in serum are not as consistent as those found in lymph. Shedlovsky and Scudder (13) described an increase of the $\alpha$ globulin fraction in the plasma of a patient suffering from burns. Similar trends are indicated in our findings although the changes are rather small. In Experiment 4, a considerable increase of the $\gamma$-fraction was found but these samples were hemolyzed. Since the red color zone, due to the pigment, migrated with the $\gamma$ peak, we feel that the increase in this component is explained by the large amount of hemoglobin present.

TABLE III

Comparison of the electrophoretic distribution of the proteins in lymph and tissue fluid from the burned area

\begin{tabular}{|c|c|c|c|c|c|c|c|c|c|c|c|c|c|c|}
\hline \multirow{3}{*}{$\begin{array}{l}\text { Experi- } \\
\text { ment } \\
\text { number }\end{array}$} & \multirow{3}{*}{ Material } & \multirow{3}{*}{$\underset{\text { burn }}{\text { Time after }}$} & \multirow{3}{*}{$\mathrm{pH}$} & \multirow{3}{*}{$\begin{array}{c}\text { Total } \\
\text { protein }\end{array}$} & \multicolumn{5}{|c|}{ Concentrations in per cent as } & \multicolumn{5}{|c|}{$\begin{array}{c}\text { Mobilities } \\
\mathrm{cm} .2^{2} \cdot \text { volt }^{-1} \cdot \text { sec. }^{-1} \cdot 10^{-6}\end{array}$} \\
\hline & & & & & \multirow{2}{*}{$\underset{\text { bumin }}{\text { Al- }}$} & \multicolumn{3}{|c|}{ Globulins } & \multirow{2}{*}{$\mathbf{s}$} & \multirow{2}{*}{$\underset{\text { bumin }}{\mathrm{Al}-}$} & \multicolumn{3}{|c|}{ Globulins } & \multirow{2}{*}{$\mathbf{s}$} \\
\hline & & & & & & $\alpha$ & $\beta$ & $\gamma$ & & & $\alpha$ & $\boldsymbol{\beta}$ & $\gamma$ & \\
\hline 8 & $\begin{array}{l}\text { Lymph: Unburned leg } \\
\text { Burned leg } \\
\text { Tissue fluid }\end{array}$ & $\begin{array}{l}\text { hours } \\
6 \text { to } 8 \\
6 \text { to } 8 \\
7 \text { to } 11\end{array}$ & 8.6 & $\begin{array}{c}\text { grams per } \\
100 \text { cc. } \\
2.75 \\
3.60 \\
4.98\end{array}$ & $\begin{array}{l}60.0 \\
49.7 \\
53.2\end{array}$ & $\begin{array}{l}14.6 \\
15.6 \\
14.5\end{array}$ & $\begin{array}{l}13.1 \\
19.1 \\
14.5\end{array}$ & $\begin{array}{r}12.3 \\
9.9 \\
10.5\end{array}$ & $\begin{array}{l}5.7 \\
7.3\end{array}$ & $\begin{array}{l}7.7 \\
7.7 \\
7.9\end{array}$ & $\begin{array}{l}5.4 \\
5.6 \\
5.6\end{array}$ & $\begin{array}{l}3.5 \\
3.4 \\
3.5\end{array}$ & $\begin{array}{l}2.2 \\
2.2 \\
2.1\end{array}$ & $\begin{array}{l}1.1 \\
1.1\end{array}$ \\
\hline 11 & $\begin{array}{l}\text { Lymph: Unburned leg } \\
\text { Burned leg } \\
\text { Tissue fluid }\end{array}$ & $\begin{array}{l}2 \text { to } 5 \\
2 \text { to } 5 \\
6 \text { to } 8\end{array}$ & 7.7 & $\begin{array}{l}2.74 \\
3.54 \\
3.83\end{array}$ & $\begin{array}{l}63.6 \\
59.4 \\
60.6\end{array}$ & $\begin{array}{r}9.2 \\
10.1 \\
10.8\end{array}$ & $\begin{array}{l}12.7 \\
12.0 \\
12.65\end{array}$ & $\begin{array}{l}14.5 \\
14.5 \\
15.95\end{array}$ & 4.0 & $\begin{array}{l}6.1 \\
6.1 \\
6.3\end{array}$ & $\begin{array}{l}4.5 \\
4.5 \\
4.9\end{array}$ & $\begin{array}{l}3.5 \\
3.5 \\
3.8\end{array}$ & $\begin{array}{l}2.1 \\
2.1 \\
2.3\end{array}$ & 1.1 \\
\hline
\end{tabular}




\section{DISCUSSION}

It has been pointed out in a previous paper (1) that these studies represent an attempt to distinguish what might be termed "primary" effects of the burn from "secondary" ones. Study of the distribution of proteins in lymph from burned tissue reveals that the injury causes an immediate increase in the permeability of the capillary walls in the area, permitting both the increased passage of the plasma proteins and a decrease in the differential permeability to albumin. A new electrophoretic boundary, appearing in tissue fluid and lymph from the burned leg alone, indicates that the newly described " $\mathrm{s}$ " component is a result of the injury. No experiments to identify the chemical nature of this component have been carried out so far. The fact that we are dealing with a non-dialyzable substance and its migration in an electric field, leads to the assumption that this is a protein-like substance. If the distribution of albumin, $\alpha$-, $\beta$-, and $\gamma$-globulins of lymph derived from the burned tissue is calculated without taking into account the refractive index area due to the " $s$ " fraction, the relative concentration of these components has changed only slightly. It therefore seems possible that we are dealing, in the case of the "s" component, with a foreign protein; $e . g$., a tissue protein released by cellular destruction into the lymphatic system. The low concentration of this component and the dilution involved may explain why it could not be detected by electrophoresis in the serum.

The change in the plasma protein picture following burns is one involving the $\alpha$-globulins. While in the present experiments we have found only a small increase in the $\alpha$-globulin:total serum protein ratio, and no actual increase in the concentration of $\alpha$-globulin in serum, in the experiment published by Shedlovsky and Scudder (13) and unpublished results from this laboratory, an actual increase of the $\alpha$-fraction in serum and plasma was demonstrated. Thus, the rise in the amount of $\alpha$-globulin might represent a secondary effect of the burn.

\section{SUM MARY}

Electrophoretic patterns of normal lymph and serum have been obtained and have been compared with those of lymph and serum after the animal was subjected to burns.

Normal lymph has the same four electrophoretic components as are present in serum: albumin, $\alpha-, \beta$-, and $\gamma$-globulin.

The pattern obtained from lymph derived from the burned tissue revealed the ocurrence of an additional boundary, migrating with half the speed of the $\gamma$-globulin.

The changes found in serum indicated a slight decrease of the albumin:globulin ratio with an increase in the $\alpha$-globulin fraction.

Inclusion of this paper in this number of the JourNaL of Clinical Investigation was made possible by the Josiah Macy, Jr. Foundation, at the request of the editors, in order to provide prompt publication of results of investigation particularly relevant to military medicine.

\section{BIBLIOGRAPHY}

1. Glenn, W. W. L., Muus, J., and Drinker, C. K., Observations on the physiology and biochemistry of quantitative burns. J. Clin. Invest., 1943, 22, 451.

2. Tiselius, A., A new apparatus for electrophoretic analysis of colloidal mixtures. Tr. Faraday Soc., 1937, 33, 524.

3. Longsworth, L. G., A modification of the Schlieren method for use in electrophoretic analysis. J. Am. Chem. Soc., 1939, 61, 529.

4. Longsworth, L. G., Cannan, R. K., and MacInnes, D. A., An electrophoretic study of the proteins of egg white. J. Am. Chem. Soc., 1940, 62, 2580.

5. Tiselius, A., and Kabat, E. A., An electrophoretic study of immune sera and purified antibody preparations. J. Exper. Med., 1939, 69, 119.

6. Davis, B. D., and Cohn, E. J., The influence of ionic strength and $\mathrm{pH}$ on electrophoretic mobility. Ann. New York Acad. Sci., 1939, 39, 209.

7. Longsworth, L. G., Recent advances in the study of proteins by electrophoresis. Chem. Rev., 1942, 30, 323.

8. Cohn, E. J., The properties and functions of the plasma proteins, with a consideration of the methods for their separation and purification. Chem. Rev., 1941, 28, 395.

9. Svensson, $H$., Fractionation of serum with ammonium sulfate and water dialysis, studied by electrophoresis. J. Biol. Chem., 1941, 139, 805.

10. Jameson, E., Alvarez-Tostado, C., and Sortor, H. H., Electrophoretic studies on new-born calf serum. Proc. Soc. Exper. Biol. and Med., 1942, 51, 163.

11. Longsworth, L. G., Shedlovsky, T., and MacInnes, D. A., Electrophoretic patterns of normal and pathological human blood serum and plasma. J. Exper. Med., 1939, 70, 399.

12. Longsworth, L. G., and MacInnes, D. A., The interpretation of simple electrophoretic patterns. J. Am. Chem. Soc., 1940, 62, 705.

13. Shedlovsky, T., and Scudder, J., A comparison of erythrocyte sedimentation rates and electrophoretic patterns of normal and pathological human blood. J. Exper. Med., 1942, 75, 119. 